\title{
Anemia Prevalence and Risk Factors among Infants Al Waleedia Health Center, Assiut
}

\author{
Saeed S.A. Soliman ${ }^{1}$ Nesreen A.Assem ${ }^{2}$, Kauthar Abdulmotagaly ${ }^{3}$ \\ ${ }^{1}$ Department of Family Medicine, Faculty of Medicine -Cairo University, ${ }^{2}$ Ministry of Health, Assuit \\ Governorate, ${ }^{3}$ Department of Community Medicine, Faculty of Medicine, Assiut University, Egypt
}

\begin{abstract}
:
Background: Anemia is one of micronutrient deficiencies which have serious public health significance in the world. In developing countries, it affects $46-66 \%$ of children aged less than five years. Several authors have demonstrated that children aged 6 to 24 months present greater vulnerability to anemia, iron deficiency anemia during this age leads to impairments in the cognitive and behavioral development and growth that persist even after treatment of iron deficiency. In Egypt few studies were done on this age group of infants and early children, even though the importance of this period. Objectives: This study aims at estimating the prevalence of anemia among children aging 12-24months in Al-Waleedia Health Center, Assiut city and to identify associated risk factors of anemia in young children. Methods: A cross sectional study was conducted on 322 child aged between 12 and 24months attended the healthy pediatric clinic at Al-Waleedia Health Center in Assiut city and their mothers. Interview questionnaire covering child and maternal characteristics was used. Results: Prevalence of anemia among the studied children was (41.6\%), maternal anemia during pregnancy and lack of child supplementation with iron were the most significant risk factors associated with iron deficiency anemia in children Conclusion: Prevalence of iron deficiency anemia among children aging 12-24 months in Al-Waleedia Health Center, Assiut city was high and considered a serious public health problem, according to the WHO global classification.
\end{abstract}

Keywords: Anemia, Children, Iron.

\section{Introduction:}

Early child development is a cornerstone of human development and should be central to how we judge the success of societies. ${ }^{(1)}$ It forms the foundation for children's future well-being and learning. ${ }^{(2)}$ Anemia in children is of particular interest since it impairs their mental, physical and social development; causes negative behavioral and cognitive effects resulting in poor school performance and work capacity in later years. ${ }^{(3)}$

Iron deficiency (ID) is indicated as the most common cause of anemia in under-five children, especially the first two years with a smaller proportion due to other micronutrient deficiency such as folate, vitamin $\mathrm{A}$ and B12.(4)Several studies have shown that iron deficiency anemia (IDA) during the first two years of life leads to impairments in the cognitive and behavioral development and growth that persist even after treatment of iron deficiency. ${ }^{(4,5)}$

The 2008 World Health Organization (WHO) estimate of anemia prevalence in Africa was (64.6\%), which is almost 50 percentage points higher than the prevalence in Europe (16.4\%), and over 60 percentage points higher than in North America (3.4\%). ${ }^{(6)}$ Nutritional studies done in Egypt over the last 30 years revealed that anemia is a moderate to severe public

*Corresponding author: E-mail: drmaha_wahdan@med.asu.edu.eg 
health problem among children. Information on anemia levels obtained in the 2005 by Egypt Demographic and Health Survey (EDHS) showed a prevalence of $(37 \%-52 \%)$ among Egyptian children aged 12-36 months. ${ }^{(7)}$ According to the EDHS 2014 report, IDA appears to be declining, the proportion of children $<5$ years with anemia in the 2014 EDHS was at $27.2 \% .^{(8)}$

Factors associated with anemia among children are complex and multidimensional. These involve socioeconomic, nutritional and biological, understanding these factors in a given population are important for evidence based interventions and policies towards anemia. $^{(9)}$

There are no enough epidemiological statistics on the prevalence of iron deficiency anemia and influence of maternal, social factors in 1224 months children in Upper Egypt, especially in Assiut Governorate. Therefore, we conducted an epidemiological study on iron deficiency anemia among 12-24 months children in Assiut. Objectives: This study aims at estimating the prevalence of anemia among children aging 12-24 months in AlWaleedia Health Center, Assiut city and to identify associated risk factors of anemia in young children.
Methods: This is a cross-sectional study conducted in Al-Waleedia Health Center in Assiut city, from October 2017 to April 2018 on apparently healthy children aged between one to two years attending the healthy pediatric clinic for vaccination and growth follow up. Al-Waleedia neighborhood is a district of Assiut city, located on about 2 square kilometers, The population is around 83,000 . The following inclusion criteria were considered; all children aged 12-24 months whose mothers agreed to participate. However the exclusion criteria were: children with chronic diseases and any child who came with another caregiver rather than the mother.

Sampling and Sample Size: The total number of children participated in this study was 322 children. The sample size was calculated using Epi Info Version 7 software guided by power test of $(80 \%)$, confidence level of 95\%, and $\alpha$ error of $(5 \%)$ and estimated previous prevalence of $(25.1 \%)$ in urban upper Egypt ${ }^{(8)}$ the minimal requested number for the study was 123 Child.

Study tools: A semi structured questionnaire was used by the researcher and data was collected by personal interview with each mother who participated in the study. The questionnaire covered child personal characteristics (name, sex, age, etc.) and data 
at birth (birth weight, was one or twin, birth order), breast feeding and feeding practices (time of introduction, types of foods) and iron supplementation, also it covered some maternal characteristics ( educational level, number of pregnancies, anemia during pregnancy with this child, etc.)

Weight and height for each child were measured and compared to WHO Growth Charts according to the age and sex. A biochemical analyzer (Master T, SN1150276ITALY2014) in the center used to determine hemoglobin concentration from a capillary blood sample collected from the fingertip of each child aseptically, using sterile single-use disposable lancet.

Diagnosis of anemia was done according to the WHO level of HB below which anemia is said to be present which is $<11 \mathrm{~g} / \mathrm{dl}$ in children aged 6-59 months. The cutoff values for the various levels of severity were: $<7 \cdot 0 \mathrm{~g} / \mathrm{dl}$ for severe anemia, 7·0-9.9 $\mathrm{g} / \mathrm{dl}$ for moderate anemia and $10 \cdot 0-10 \cdot 9 \mathrm{~g} / \mathrm{dl}$ for mild anemia ${ }^{\cdot(10)}$

Data management: The data were entered in a Microsoft EXCEL spreadsheet, revised, cleaned and analyzed using the Statistical Package for Social Science (SPSS version 16). Descriptive statistics were done in the form of frequencies, mean and standard deviation, then suitable tests of significance as
Chi-square was used. Values were considered significant when $\mathrm{P}$ values were $<0.05$. Multivariate logistic regression analysis was done to determine the potential factors associated with iron deficiency anemia for the included study participants.

Ethical considerations: Protocol of this study was prepared and approved by the Ethics and Research Committee Board (IRB) in the Faculty of Medicine, Assiut University. Participants were informed about the objectives and methods of the study and oral consent was obtained. Confidentiality of all the information was maintained by removing the names of the children from data collection sheet. The mothers did not pay for hemoglobin assessment which is a routine investigation for their children on their visits to the center.

Results: 322 young children aged between 12 and 24 months attended AL-Waleedia Health Center, Assiut city and their mothers were included aiming to find out the prevalence and risk factors of anemia in children. The age of the studied children ranged from 12 to 23 months as shown in table 1. Only 151 children took iron supplementation (46.9\%) and nearly (55\%) were exclusively breastfed children during the first 6 months of life (delayed weaning). More than one quarter of 
the children were underweight and (14\%) were stunted as shown in figure 1,2.

Yoghurt was the main food eaten by children, only $28.6 \%$ received foods rich in iron (eggs, liver, meat, fortified cereals, etc.) while more than quarter of the children depended mainly on the traditional foods (nonnutritive starchy foods and sweets) figure 3.

More than half of the mothers had the secondary school level of education, the other half had university and above education, only 8 were illiterate. Spacing between this child and the older was less than 24 months in about $(77 \%)$ of mothers. About $(66 \%)$ of mothers were anemic at the pregnancy with this child.

Table (3) shows statistical significant difference between child sex and age and anemia, being higher in females (47.2\%) and in younger than18 months (50.3\%). Also, there is a statistical significant difference between anemia and underweight and stunting in anemic children; about 36.6 of normal weight children were anemic while more than $(55 \%)$ of underweight were anemic. A statistical significant difference was found between anemia and the introduction of foods rich in iron, around $(27 \%)$ of children who had foods rich in iron found to be anemic while about (47.4\%) were anemic in children did not have these foods.

There was a statistical significant difference between anemia and previous iron supplementation that made anemia lower in those children supplemented with iron, $(13.2 \%)$ of them were anemic, while more than $(65 \%)$ of children who did not have iron supplement were anemic. There was a statistical significant difference between the introduction of traditional foods and anemia; anemia was less in children who did not have these nonnutritive foods $(37.1 \%)$, while about $(54.9 \%)$ were found to be anemic in children who had those foods. Cow milk made anemia higher in those children early depended on it. About (57\%) were anemic compared to (39\%) anemic children among those who did not depend early on cow milk.

Table (3) shows a statistical significant difference between anemia in children and mother education, being higher in children of illiterate and secondary educated mothers $(60 \%)$ compared to $(23 \%)$ anemic children among children of highly educated mothers. There was a statistical significant difference between anemia and the duration between the child and the older being higher when duration is less than 24 months. More than 
half of that group was anemic (53\%), while anemia was less in children with spacing was more than 24 months (20\%). Anemia during pregnancy with this child had a statistical significant difference to anemia as the study showed that babies born to anemic mothers are more prone to develop IDA than children of non-anemic mothers, about $(60 \%)$ of anemic mothers had anemic infants compared to only $(17 \%)$ anemic children to healthy mothers.

There was no statistical significance difference between anemia and the age of child at the start of weaning (period of exclusive breastfeeding) and no significant difference was found between anemia and mother age and number of pregnancies.

All significant factors were entered in logistic regression analysis to identify and rank significant predictors of anemia. It was found that anemia during pregnancy and lack of child supplementation with iron were the most significant risk factors for anemia in those children as shown in table (3).

Discussion: The prevalence of IDA was $(41.6 \%)$ among the studied group, this was nearly similar to the results of an Egyptian study conducted in Cairo on 300 infants aged 6 to 24 months and found that the prevalence was $(43 \%),{ }^{(1)}$ and less than other Egyptian study where the prevalence of IDA was (57.1\%) among 147 infants aged between 6to24 months in El-Menoufia. ${ }^{(12)}$ When compared to other developing countries, the prevalence of IDA was (72\%) among 232 infants aged 3 to 12 months in Jordan. ${ }^{(13)}$ On the other hand, in developed countries the prevalence of IDA is much lower as in the United States (3.6\%) and the average of developed European countries (7\%). ${ }^{(14)}$

The high prevalence of iron deficiency among our study population might be explained by the high prevalence of iron deficiency observed in history of pregnancy among participated mothers $(54.7 \%)$. The babies are already born with poor iron stores and faulty weaning practices where the transition from full lactation to the family diet occurs within the first 2 years of life. During this period, weaning foods are mainly rice and starch and unfortified cow's milk deficient in iron unmet increased needs for iron due to rapid growth. This emphasizes the importance of prophylactic iron supplements recommended by CDC for children between 6 and 24 months, which is not applied in Egypt. ${ }^{(15)}$ This high prevalence is enough to consider IDA a severe public health problem according to the WHO classification. ${ }^{(16)}$ 
According to sex, the frequency of IDA was higher among girls (56.7\%),this agrees with an Egyptian study conducted in El-Menoufia among 6 to 24aged children with near result as anemia found higher in females $(52.2 \%)^{(12)}$, but not in agreement with many studies which found that IDA was predominant in boys than girls. $^{(17)(18)}$

In this study a significant strong relationship between anemia in children and some maternal characteristics, including mother education, anemia during pregnancy with this child and duration between pregnancies. One of the most important risk factors associated with anemia in children is maternal anemia during pregnancy thas was found by this study and other many studies. ${ }^{(12,19,20)}$

This study emphasized the importance of maternal education on the children's health. It was found that children of low educational level and illiterate mothers are more prone to develop IDA than children of mothers with higher educational levels with statistically significant difference due to lack of knowledge of basic food requirements and awareness of food rich in iron. This is in accordance with similar studies reported that the mean HB levels were lower among children of illiterate mothers. ${ }^{(21)}$ This study detected that there was a positive relation between anemia and consumption of cow milk, and this was the same as many studies $^{(22,23)}$

The current study highlighted 'feeding children with low iron containing foods' was a significant predictor of IDA, which agrees with previous similar studies. ${ }^{(11,24)}$ There was a significant association between the consumption of food rich in iron and IDA, including animal meat, chicken meat, liver, eggs, and fortified cereals. Iron absorption enhancers as fruits; this is in agreement with a study done in Jeddah-Saudi Arabia on females. ${ }^{(25)}$

In the present study, the absence of iron supplements was strongly associated with anemia, reinforcing the importance of iron supplementation to prevent this deficiency in infants. More than $(40 \%)$ of studied children did not receive iron supplements any more, among infants received iron supplements, only $(13.2 \%)$ had anemia this reflect the protective effect of iron supplementation against anemia which agrees with several studies. ${ }^{(26,27)}$

This study showed that stunting and underweight were associated with iron deficiency anemia among children. This agrees with Soliman, et al. ${ }^{(28)}$,and also Hassan. A et al., in a study conducted in El- 
Minofia Egypt on 400 school children mentioned that children with anemia were shorter for their age, and a higher percentage of them had stunted growth. ${ }^{(29)}$

This study showed that age of mother, number of pregnancies and duration of exclusive breastfeeding (age of starting weaning foods) were not significant risk factors in relation to anemia.

Duration of exclusive breastfeeding had no clear association with anemia in this study. This in agreement with a study done in Mexico on 6 to 23 months old children and found the same. ${ }^{(30)}$ However, many other studies indicated that breastfeeding beyond 6 months of age is associated with poor iron status. ${ }^{(31)}$

Conclusion: The prevalence of iron deficiency anemia among children aged 12-24 months in Al-Waleedia Health Center, Assiut city was high and represents a serious public health problem. The most significant risk factors associated with anemia in the studied group were anemia during pregnancy and lack of child iron supplementation. There was a significant association between anemia in young children and educational level of the mother, spacing between pregnancies and late introduction of foods rich in iron to the child. No significant association was found between anemia and age of child at the start of weaning (period of exclusive breast feeding), and mother age or number of pregnancies.

\section{Conflict of interest:}

The authors state that they have no competing interests.

\section{Funding:}

There has been no significant financial support for this work that could have influenced its outcome.

\section{References:}

1. World Health Organization. 10 Facts About Early Child Development As a Social Determinant of Health, 2-3.(2012) Retrieved from http://www.who.int/maternal_child_adoles cent/topics/child/development/10facts/en/

2. UNICEF. (2006). Guidelines for early childhood development services south Africa: Every child has the right to the best possible start in the lifeAvailable:http://www.unicef.org/southa frica/SAF_resources_ecdguidlines.pdf

3. Villalpando S, Shamah-Levy T, RamírezSilva CI, Mejía-Rodríguez F, Rivera JA. Prevalence of anemia in children 1 to 12 years of age.Results from a nationwide probabilistic survey in Mexico. Saludpública de México. 2003;45(S4):4908. 
4. Ewusie JE, Ahiadeke C, Beyene J, Hamid JS. Prevalence of anemia among under-5 children in the Ghanaian population: estimates from the Ghana demographic and health survey. BMC public health. 2014 Dec;14(1):626.

5. Irwin JJ, Kirchner JT. Anemia in children. American family physician. 2001 Oct $15 ; 64(8)$.

6. Baker RD, Greer FR. Diagnosis and prevention of iron deficiency and irondeficiency anemia in infants and young children (0-3 years of age). Pediatrics. 2010 Nov 1;126(5):1040-50.

7. Austin, A.M.; Fawzi, W.; Hill, A.G. Anaemia among Egyptian Children between 2000 and 2005: Trends and predictors. Matern.Child.Nutr. 2012, 8 , $522-532$.

8. Ministry of Health and Population; ElZanaty and Associates; DHS Program ICF International. Egypt Demographic and Health Survey 2014: Main Findings. Available online: http://dhsprogram.com/pubs/pdf/PR 54/PR54.pdf

9. Semba RD, Bloem MW. The anemia of vitamin A deficiency: epidemiology and pathogenesis. European journal of clinical nutrition. 2002 Apr;56(4):271.
10. World Health Organization. Hemoglobin concentrations for the diagnosis of anemia and assessment of severity.Vitamin and Mineral Nutrition Information System. Geneva: 2011. World Health Organization (WHO/NMH/NHD/MNM/11.1). 2017.

11. Elalfy MS, Hamdy AM, Maksoud SSA, Megeed RIA. Pattern of milk feeding and family size as risk factors for iron deficiency anemia among poor Egyptian infants 6 to 24 months old. Nutr Res. 2012;32(2):93-9.

12. Fahima M. Hassan, Fady M. El-Gendy HSB, Samar M. Kamal El-din DMME. Evaluation of iron-deficiency anemia in infancy. Menoufia Med J. 2016;29:269274.

13. Kibride J, Baker T, Parapia L, Khoury S. Incidence of iron deficiency anemia in infants in a prospective study in Jordan. Eur J Haematology. 2000;64:231-236.

14. Cusick SE, Mei Z, Freedman DS, et al. Unexplained decline in the prevalence of anemia among US children and women between $1988-1994$ and $1999-2002$. Am J Clinic Nutrition. 2008;88:1611-1617

15. Soliman GZA, Azmi MN, El-S S. Prevalence of Anemia in Egypt (AlGharbia Governorate). Egypt J Hosp Med. 2007;28(2):95-105. 
16. WHO, Worldwide Prevalence of Anemia 1993-2005: WHO Global Database on Anemia, World Health Organization, Geneva, Switzerland, 2008.

17. Sayed NE, Gad A, Nofal L, Netti G. Assessment of the prevalence and potential determinants of nutritional anemia in Upper Egypt. Food Nutr Bull 1999;20:417421

18. Akarsu S, Kilic M, Yilmaz E, Aydin M, Taskin E, Aygun AD. Frequency of hypoferritinemia, iron deficiency and iron deficiency anemia in outpatients. Acta Haematol. 2006;11

19. Hou XQ, Li HQ. Effect of maternal iron status on infant's iron level: a prospective study. Zhonghua er ke za zhi= Chinese $\mathrm{J}$ Pediatr. 2009;47(4):291-5.

20. Shao J, Lou J, Rao R, Georgieff MK, Kaciroti N, Felt BT, et al. Maternal Serum Ferritin Concentration Is Positively Associated with Newborn Iron Stores in Women with Low Ferritin Status in Late Pregnancy--. J Nutr. 2012;142(11):2004 9.6(1):46-50.

21. Neve Vendt1, Heli Grünberg1, 2, Sirje Leedo3, Vallo Tillmann1, 2, Tiina Talvik1 Prevalence and causes of iron deficiency anemias in infants aged 9 to 12 months in
Estonia Medicina (Kaunas) 2007; 43(12) 947

22. Male C, Persson LA, Freeman V, Guerra A, van'tHof MA, Haschke F, et al. Prevalence of iron deficiency in 12-mo-old infants from11 European areas influence of dietary factors on iron status (Euro-Growth study). ActaPaediatr. 2001;90:492-8.

23. Mira M, Alperstein G, Karr M, Ranmuthugala G, Causer J, Niec A, Lilburne AM. Haem iron intake in 12-36 month old children depleted in iron: casecontrol study. BMJ. 1996 Apr 6;312(7035):881-3.

24. Capozzi L, Russo R, Bertocco F, Ferrara D, Ferrara M. Diet and iron deficiency in the first year of life: a retrospective study. Hematology. 2010;15(6):410-3.

25. Gari MA. Prevalence of iron deficiency anemia among female elementary school children in Northern Jeddah, Saudi Arabia. Med Sci. 2008;15(1).

26. Tielsch JM, Khatry SK, Stoltzfus RJ, Katz J, LeClerq SC, Adhikari R, Mullany LC, Shresta S, Black RE. Effect of routine prophylactic supplementation with iron and folic acid on preschool child mortality in southern Nepal: community-based, clusterrandomised, placebo-controlled trial. The lancet. 2006 Jan 14;367(9505):144-52. 
27. BergerJ, Dyck JL, Galan.P et al. Effect of daily iron supplementation on iron status, cell-mediated immunity, and incidence of infections in 6-36 month old Togolese children. 2000. 54:29-35.

28. Soliman GZA, Azmi MN, El-S S. Prevalence of Anemia in Egypt (AlGharbia Governorate). Egypt J Hosp Med. 2007;28(2):95-105.

29. Hassan FM, El-Gendy FM, Badra HS, Eldin SMK, Elsayyad DMM, others.
Evaluation of iron-deficiency anemia in infancy. Menoufia Med J. 2016;29(2):269.

30. Prieto-Patron A, der Horst K, Hutton Z, Detzel P. Association between Anaemia in Children 6 to 23 Months Old and Child, Mother, Household and Feeding Indicators. Nutrients. 2018;10(9):1269.

31. Calvo E.B., Galindo A.C. AN. Iron status in exclusively breast-fed infants. Pediatrics. 1992;90:375-9 
Table (1): Personal characteristics of the studied children and their mothers

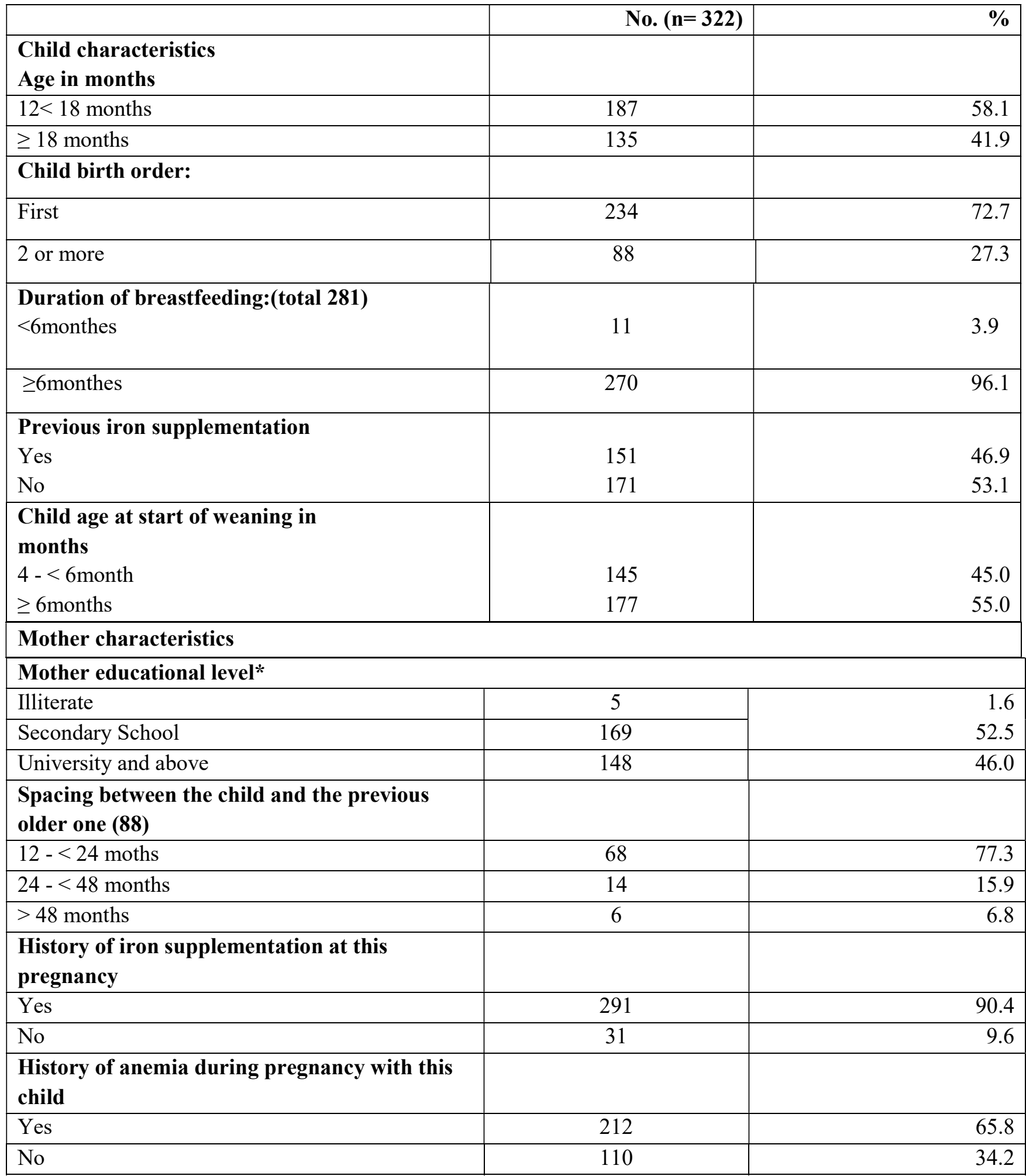

*No primary or secondary educational level found among mothers.. 


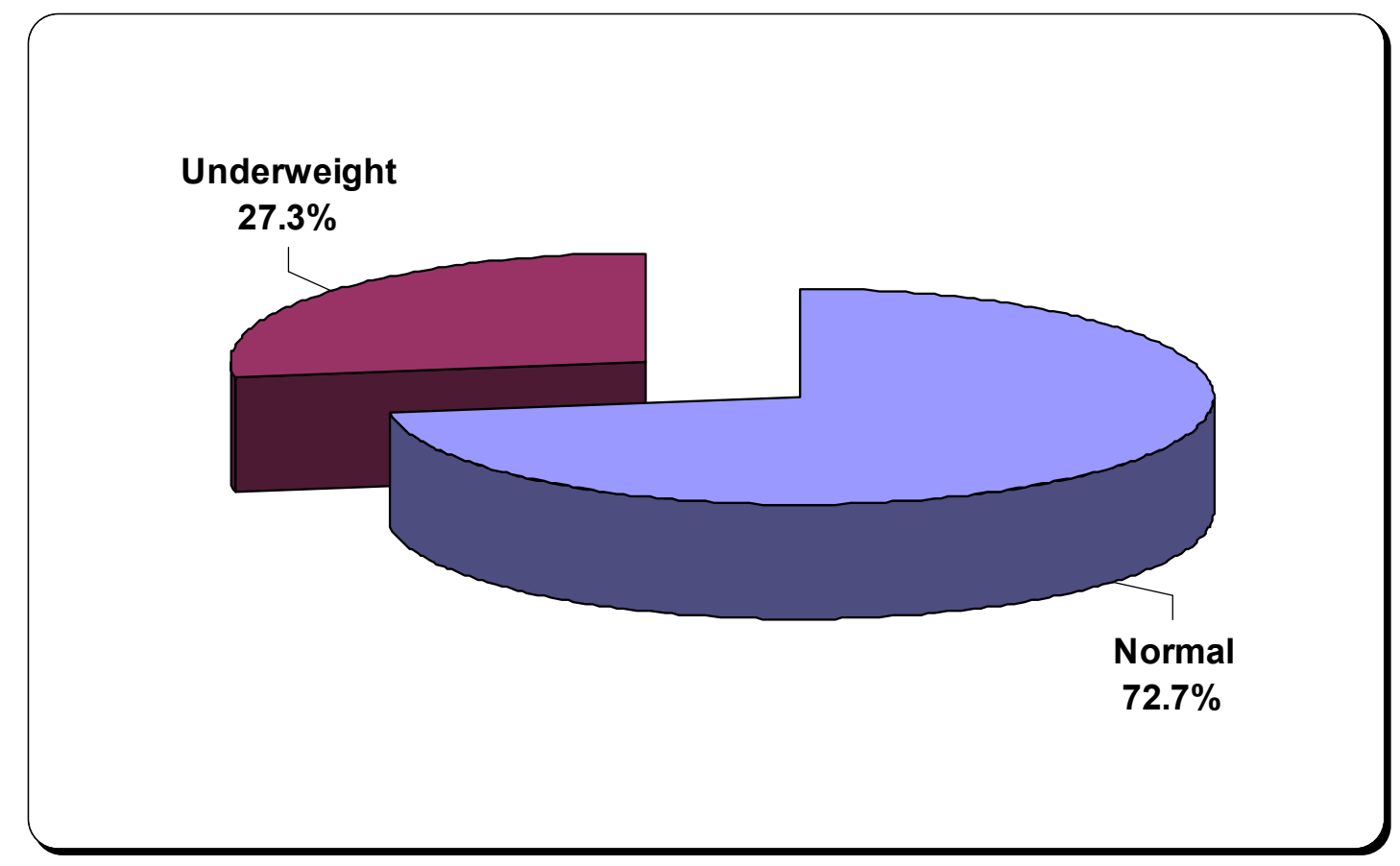

Figure(1): Weight for age among studied children, Al-Waleedia neighborhood, Assuit city, 2018 


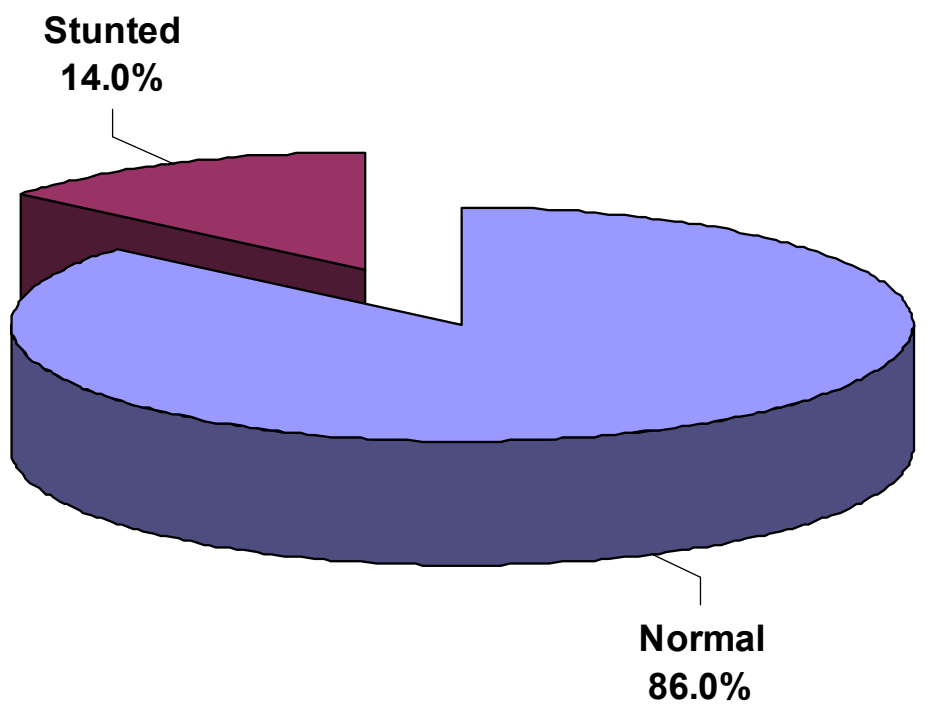

Figure (2): Height for age among studied children, Al-Waleedia neighborhood, Assuit city, 2018

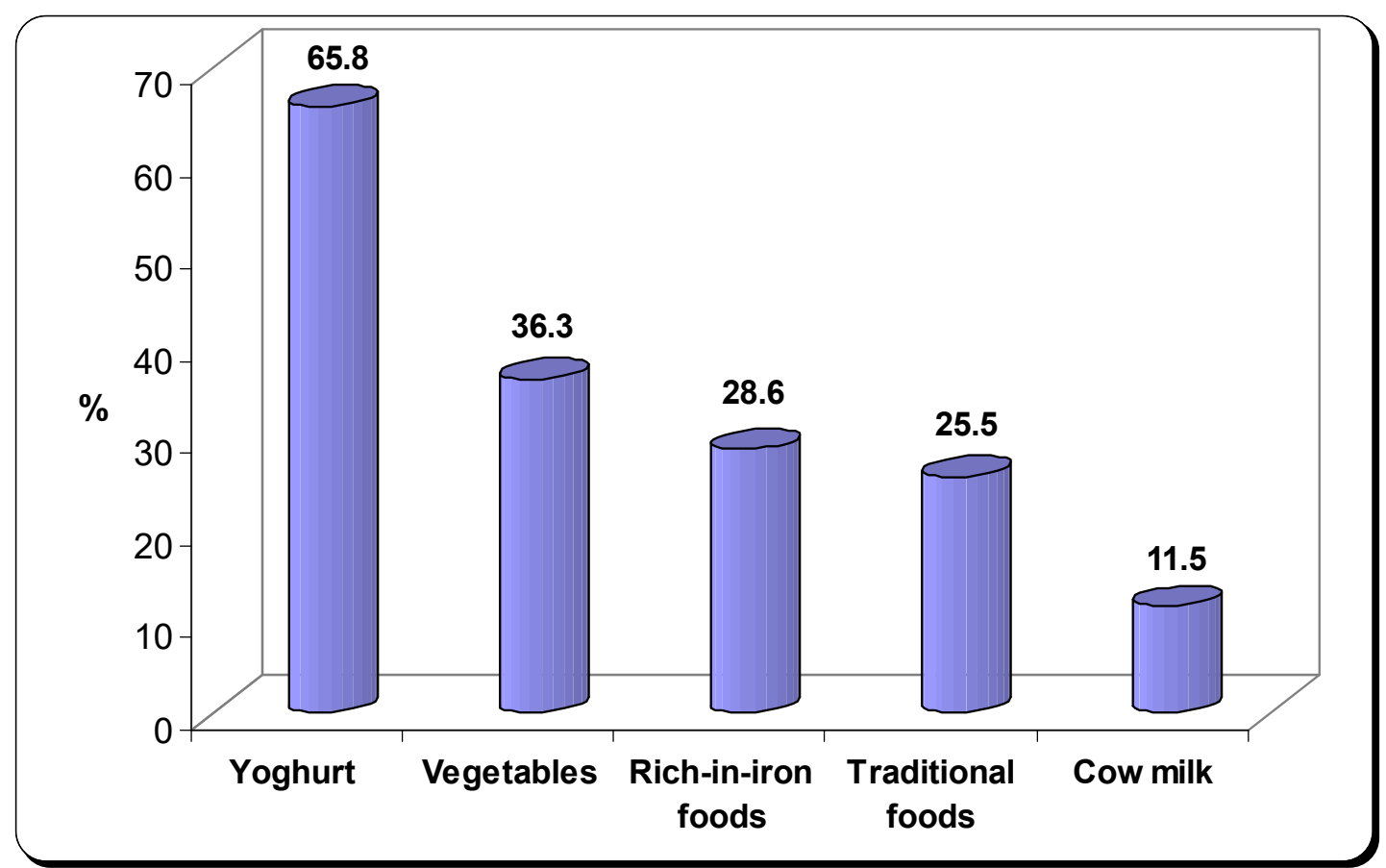

*More than one item included in answers, so summation is more than $100 \%$

Figure (3): Main complementary foods introduced to studied children 
Table (2): Relation between child and mother characteristics and anemia






\begin{tabular}{|l|l|l|l|l|}
\hline Mother characteristics & \multirow{2}{*}{$0.001^{*}$} \\
Mother education level & 3 & 60.0 & 2 & 40.0 \\
\hline Illiterate & & & & \\
\hline Secondary school & 97 & 57.4 & 72 & 42.6 \\
\hline University and above & 34 & 23.0 & 114 & 77.0 \\
\end{tabular}

\begin{tabular}{|c|c|c|c|c|c|}
\hline \multicolumn{5}{|c|}{ Spacing between the child and the older } & \multirow[b]{3}{*}{$0.02 *$} \\
\hline $12-<24$ moths & 36 & 52.9 & 32 & 47.1 & \\
\hline$\geq 24$ months & 4 & 20.0 & 16 & 80.0 & \\
\hline \multicolumn{5}{|c|}{$\begin{array}{l}\text { Anemia during pregnancy with this } \\
\text { child }\end{array}$} & \multirow{3}{*}{$<0.001^{*}$} \\
\hline Yes & 116 & 54.7 & 96 & 45.3 & \\
\hline No & 18 & 16.4 & 92 & 83.6 & \\
\hline
\end{tabular}

NB. No detected history of recurrent chronic infections $\quad *$ Chi square test was used 
Table (3): Results of multivariate logistic regression analysis of potential risk factors for anemia among studied children

\begin{tabular}{|c|c|c|c|c|}
\hline & P-value & OR & $95 \% \mathrm{C}$ & \\
\hline & & & Lower & Upper \\
\hline Age ( $<18$ months) & 0.835 & 1.074 & 0.546 & 2.113 \\
\hline Sex(female) & 0.176 & 0.636 & 0.331 & 1.224 \\
\hline Mother education less than high education & 0.067 & 1.936 & 0.955 & 3.926 \\
\hline Child had no previous iron supplement & $<0.001^{*}$ & 12.061 & 5.918 & 24.581 \\
\hline Anemia during pregnancy with this child & $<0.001^{*}$ & 5.784 & 2.755 & 12.143 \\
\hline Weight for age (Underweight) & 0.601 & 1.228 & 0.568 & 2.657 \\
\hline Height for age (stunted) & $0.001 *$ & 7.338 & 2.336 & 23.048 \\
\hline
\end{tabular}




\section{الملخص العربى}

\section{انتثار فقر الدم وعوامل الخطر بين الأطفال الذين تتراوح أعمار هم بين سنة إلى سنتين ، مركز الوليديه \\ الصحي ، أسيوط \\ سعيد صلاح عبدالجليل سليمان، نسرين أحمدعاصم ، كوثر عبد المتجلي فاضل عبد الحميد}

الخلفية: فقر الدم هو واحد من نقص المغذيات الدقيقة التي لها أهمية خطيرة في مجال الصحة العامة في العالم. في البلدان النامية ، فإنه يؤثر على 46-66 ٪ من الأطفال الذين تقل أعمار هم عن خمس سنوات. لقد أثنبت العديد من المؤلفين أن الأطفال الذين تتراوح أعمار هم بين 6 إلى 24 شهرًا يعانون من قابلية أكبر لفقر الدم ، فقر الدم الناجم عن نقص الحديد خلال هذا العمر يؤدي إلى إعاقات في النمو و النمو المعرفي و السلوكي والنمو المستمر حتى بعد علاج نقص الحديد. لم يتم إجر اء العديد من الدراسات في مصر حول الفئة العمرية للرضع والأطفال الأوائل على الرغم من أهمية هذه الفترة. الأهداف: تهدف هذه الدر اسة إلى تقدير معدل انتشار فقر الدم بين الأطفال الذين تتراوح أعمار هم بين 12 و 24 شهرًا في مركز الوليدي الصحي بمدينة أسيوط وتحديد عوامل الخطر المرتبطة بفقر الدم عند الأطفال الصغار. منهجية الاراسة: أجريت در اسة مقطعية على 322 طفلاً تتر اوح أعمار هم بين 12 و 24 شهرًا حضروا عيادة الأطفال الصحية في مركز الوليدية الصحي في مدينة أسيوط وأمهاتهم، وتم استخدام استبيان المقابلة الذي يغطي خصائص الطفل والأم. النتائج: كان معدل انتشار فقر الدم بين الأطفال الذين شملتهم الدراسة 41.6 ٪ ، وفقر الدم لدي الأمهات أثناء الحمل وعدم وجود مكملات الأطفال مع الحديد كانت أهم عوامل الخطر المرتبطة بفقر الدم بسبب نقص الحديد لدى الأطفال الخلاصة: انتشار فقر الدم بسبب نقص الحديد بين الأطفال الذين تتراوح أعمار هم بين 12-24 شهر في مركز الوليدية الصحي، مدينة أسيوط كان مرتفعا. وتعتبر مشكلة صحية عامة خطيرة وفقًا لتصنيف منظمة الصحة العالمية العالمي. 